\title{
Comparative Analysis of Various Z-source Based Five Level Cascaded H-bridge Multilevel Inverter
}

\author{
C. R. Balamurugan*, K. Vijayalakshmi \\ Department of EEE, Karpagam College of Engineering, Coimbatore, India
}

\begin{tabular}{l}
\hline \hline Article Info \\
\hline Article history: \\
Received Oct 25, 2017 \\
Revised Dec 26, 2017 \\
Accepted Jan 09, 2018 \\
\hline
\end{tabular}

\section{Keywords:}

Five level

MLI

State

THD

Z-source

\begin{abstract}
Z-source based multilevel inverters are the recent topologies as they have boosting ability and near sinusoidal output waveforms. This paper proposes different inverter topologies such as Z-source multilevel inverter and quasi Z-source multilevel inverter. This paper also deals with switched inductor and improved switched inductor topologies with quasi Z-network. The proposed switched inductor system reduces the voltage stresses caused by capacitors, power devices and diodes. In addition to multilevel inverter advantages, the proposed configuration employs Z-source inverter advantages. The $\mathrm{Z}$-source inverter as compared to the traditional inverter is less costly, less complex, more efficient and more reliable. The performance of the proposed configurations is analysed by varying passive elements in impedance network and is simulated in MATLAB/SIMULINK. Phase disposition (PD) pulse width modulation (PWM) technique is applied on the proposed configurations and performance parameters are measured by the fast Fourier transform FFT analysis. The object of this paper is to develop an inverter which is used for variable speed drives with increase in output voltage by eliminating transformer and filter circuit. The performance is checked with standared parameter of the inverter.
\end{abstract}

Copyright $(0) 2018$ Institute of Advanced Engineering and Science. All rights reserved.

\section{Corresponding Author:}

C. R. Balamurugan,

Department of EEE, Karpagam College of Engineering,

Coimbatore, India.

Email: crbalain2010@gmail.com

\section{INTRODUCTION}

Z-source inverters are recent topologies that can buck and boost a given input voltage. Both voltage source inverter (VSI) and current source inverter (CSI) have common problems. To overcome the drawbacks of the conventional inverter, Z-source inverter is proposed. A unique feature of the Z-source inverter is the shoot through state which is performed when the load terminals are shorted through both upper and lower devices of the same phase leg. In a Z-source inverter, an impedance network has two inductors and two capacitors. They are arranged in X-shape that connects the main circuit with the DC supply. The Z-source inverter can work in shoot through and non-shoot through modes. The quasi Z-source inverter qZSI is modified from the Z-source inverter. The qZSI has some advantages over the Z-source inverter. In the qZSI, the voltage stress across the switches is reduced as well as these switches will be provided with higher boost ability. Further, new topologies are proposed with the addition of passive components. In this paper, a Zsource based cascaded H-bridge inverter is proposed. From different types of multilevel inverter MLI, cascaded multilevel inverter is chosen to create a sinusoidal output waveform and reduce the switching losses. One of the biggest problems in power quality aspects is the harmonic contents in the electrical system. Generally, harmonics may be divided into two types they are 1) Voltage harmonics and 2) Current harmonics. 
Current harmonics are usually generated by harmonics contained in supply voltage and depend on the type of load such as resistive load, capacitive load and inductive load. Both harmonics can be generated by either the source or the load. Harmonics generated by load are caused by non-linear operation of devices including power converters, arc-furnaces, gas discharge lighting devices etc. Load harmonics can cause the overheating of the magnetic cores of transformer and motors. On the other hand, source harmonics are mainly generated by power supply with non-sinusoidal voltage. Voltage and current harmonics imply power losses, EMI and pulsating torque in AC motor drives. There are several methods to indicate the quantity of harmonic contents of a periodic wave. One among them is THD which is mathematically given by:

$$
\mathrm{THD}=\frac{\sqrt{\sum_{\mathrm{n}=2}^{\infty} \mathrm{H}_{\mathrm{n}}^{2}}}{\mathrm{H}_{1}}
$$

and defined in terms of the amplitudes of the harmonics Hn at frequency nw0 where w0 is frequency of the fundamental component whose amplitude is $\mathrm{H} 1$ and $\mathrm{n}$ is an integer. Since any periodic waveform can be shown to be the superposition of a fundamental and a set of harmonic components, by applying Fourier transformation, these components can be extracted. The frequency of each harmonic component is an integral multiple of its fundamental. MLIs easily produce high-power, high-voltage output with the multilevel structure because of the way the device voltage stresses are controlled in the structure. Increasing the number of voltage levels in the inverter without requiring higher ratings on individual devices can increase the power rating. The unique structure of multilevel VSI allows them to reach high voltages with low harmonics without the use of transformers or series connected synchronized switching devices. As the number of voltage levels increases, the harmonic content of the output voltage decreases significantly.

The MLIs synthesize a near sinusoidal voltage from several DC voltage sources. As the number of levels increases, the synthesized output has more steps, resembling a staircase wave that approaches a desired sinusoidal waveform. As the number of levels increases, the output voltage that can be spanned by summing multiple voltage levels also increases. MLIs have many attractive features like high voltage capability, reduced common mode voltages, near sinusoidal outputs, low dv/dt and smaller or even no output filter, making the inverters suitable for high power applications. Switched inductor and switched capacitor Z-source inverters are proposed with an addition of a few passive component networks and simulated using MATLAB. Two topologies are presented in [1] for switched inductor quasi Z-source inverters $S L$-qZSI, in which the operating principles and analysis and compare them with the conventional Z-source inverters are presented. The study [2] presented an asymmetric five level cascaded multilevel inverter using multicarrier PWM technique. The simulation results are presented to prove that THD is reduced with the multicarrier modulation. The use of a quasi Z-source inverter for advanced power conditioning of renewable energy sources are proposed in [3]. The simulation and experimental results in [4], have proven that the improved Space vector PWM method for a proposed four switch quasi Z-source converter structure without filtering circuit is more efficient algorithm. Design and analysis of a single phase switched inductor quasi Z-source inverter for photovoltaic applications is presented in study [5]. This paper presents the Z-source multilevel inverter and phase disposition PWM technique which is used to generate the gating signals for the inverter switches. An isolated step up DC/DC converter topology with quasi Z-source inverter for resistive and inductive load has been designed and analysed using MATLAB by [6]. Singh et al [7] discussed about comparative study of PWM control and PI control of induction motor. Sengolarajan et al [8] proposed three phase trinary source MLI Using multicarrier SPWM strategies. An extended switched inductor quasi Z-source inverter with high boost ability is presented in paper [9]. A high performance quasi Z-source inverter is proposed in [10] to maintain the advantages such as reduced capacitor voltage stress and limited inrush current. The study [11] achieved a reduction of switches and DC sources in a cascaded multilevel inverter. A survey on maximum power point tracking methods in photovoltaic power systems is proposed in [12]. Operating principles, analysis and simulation results of switched inductor quasi Z-source inverter are proposed in [13]. Cascaded H-bridge different level inverter using sinusoidal PWM technique is proposed by [14]. A review of multilevel inverter topology and control techniques are discussed in this paper [15]. Various topologies of Z-source inverters are analysed in [16] on the basis of size, cost and THD of the output voltage. This paper proposes a switched inductor Zsource cascaded H-bridge multilevel inverter. The principle of operation of shoot through and non-shoot through state of the proposed topology is explained in [17]. The switched capacitor/switched inductor topology is proposed in this work. Compared with other traditional topologies SC/SL topology provides higher boost ability. The proposed quasi Z-source CHB multilevel inverter with switched inductor provides extended boost output voltage with low THD !!!. In [18], Z-source neutral point clamped inverter exhibits the 
advantages of Z-source inverter, which can buck or boost the energy and allow shoot through states [19]. This paper presents the design and implementation of hardware of a basic Z-source inverter which demonstrates the boosting capability [20]. A Review [21] on Z-Source Based multilevel inverter with reduced number of switches. Simulation and analysis of improved switched inductor quasi Z-Source based multilevel inverter with reduced number of switches is presented by [22]. A review [23] is in introduced on various Z-Source fed multilevel inverter. Investigations on Z-source based cascaded five level inverter is carried out by [24]. Balamurugan et al [25] made a review on modulation strategies of multilevel inverter. Balamurugan et al [26] made a performance evaluation of 3Ф asymmetrical MLI with reduced switch count. Balamurugan et al [27] developed hardware for cascaded hybrid multilevel inverter with reduced number of switches. Z-source multilevel inverter based on embedded controller is introduced in [28]. In the present paper, Z-source and quasi Z-source based cascaded multilevel inverter is proposed and a comparative analysis for some proposed topologies is presented.

\section{MULTILEVEL INVERTER}

Multilevel inverter is a power electronic device has a unique structure, built to synthesize a desired AC output voltage from several DC sources. It has the ability to reduce the voltage stress across each power device. These properties make the multilevel inverter very attractive industry. The multilevel inverter not only can generate the output voltage with low distortion, but also reduce the $\mathrm{dv} / \mathrm{dt}$ stresses. It can operate with both fundamental switching frequency and high switching frequency PWM. Figure 1 displays the cascaded multilevel inverter.

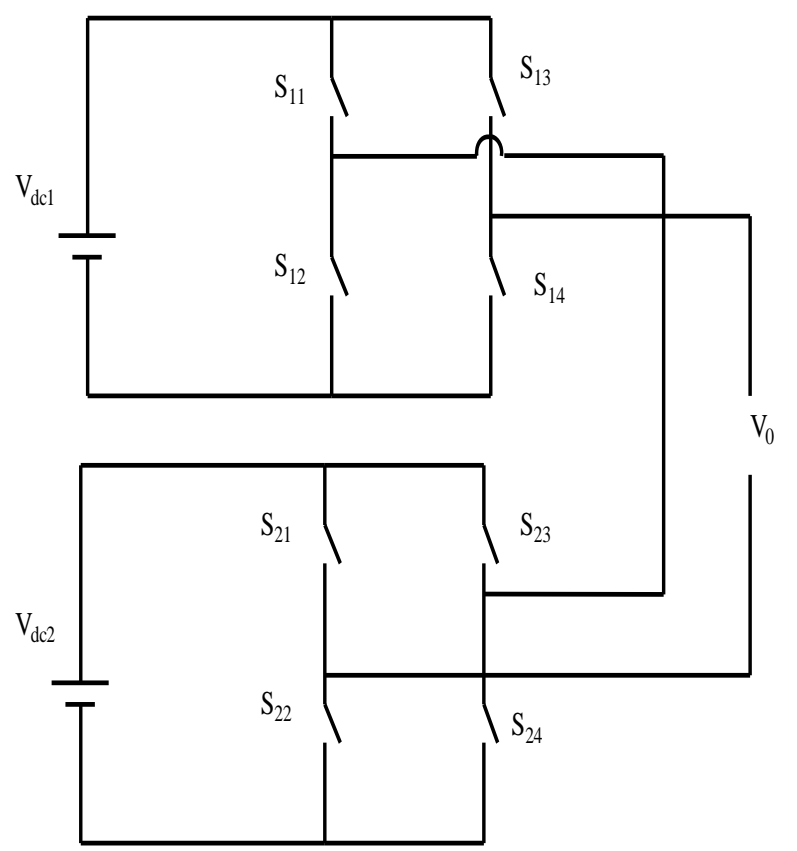

Figure 1. Conventional cascaded multilevel inverter

This cascaded configuration formed by cascading more than one H-bridge inverter in series. Each H-bridge inverter connected to its own DC source. Generally, a cascaded multilevel inverter can produce a maximum of $(2 n+1)$ level, where $n$ is the number of DC sources. In order to obtain a five level output, two modules are connected in series in a given configuration. This topology has the advantages of automatic voltage sharing across the switches in a module due to the usage of independent voltage sources. Figure 2 displays the cyclic switching states of the proposed inverter.

Each module can generate three different voltages $+\mathrm{Vdc}, 0$ and $-\mathrm{Vdc}$. Table 1 shows the possible switching states of the proposed MLI. 


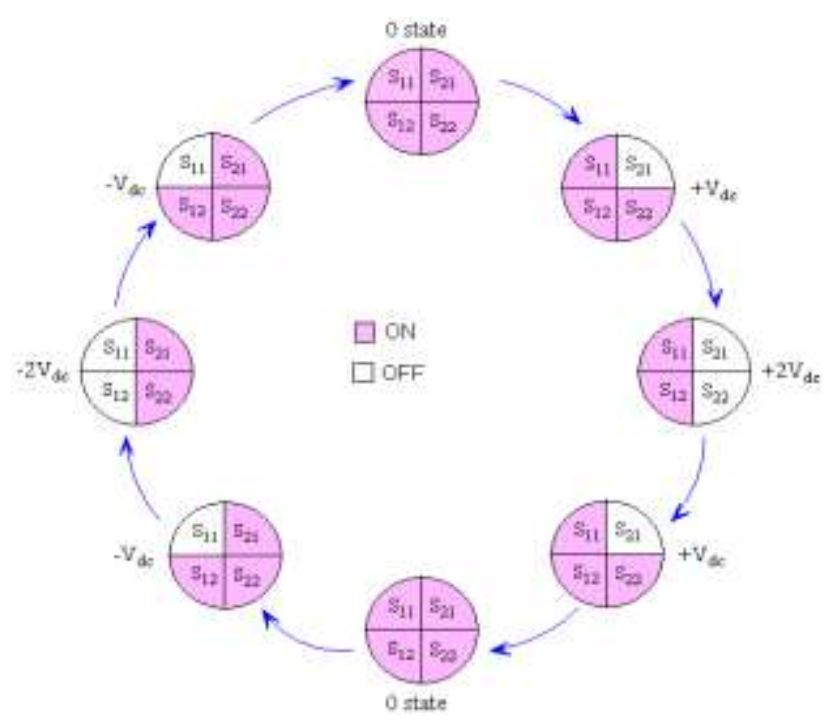

Figure 2. Cyclic switching states

Table 1. Switching States and Voltage Output

\begin{tabular}{ccccc}
\hline $\mathrm{S}_{11}$ & $\mathrm{~S}_{12}$ & $\mathrm{~S}_{21}$ & $\mathrm{~S}_{22}$ & Output $\left(\mathrm{V}_{0}\right)$ \\
\hline 1 & 0 & 1 & 0 & $+2 \mathrm{~V}_{\mathrm{dc}}$ \\
1 & 0 & 0 & 0 & $+\mathrm{V}_{\mathrm{dc}}$ \\
1 & 0 & 1 & 1 & $+\mathrm{V}_{\mathrm{dc}}$ \\
0 & 0 & 1 & 0 & $+\mathrm{V}_{\mathrm{dc}}$ \\
1 & 1 & 1 & 0 & $+\mathrm{V}_{\mathrm{dc}}$ \\
0 & 0 & 0 & 0 & 0 \\
1 & 1 & 1 & 1 & 0 \\
1 & 0 & 0 & 1 & 0 \\
0 & 1 & 1 & 0 & 0 \\
0 & 0 & 1 & 1 & 0 \\
1 & 1 & 0 & 0 & 0 \\
0 & 1 & 1 & 1 & $-\mathrm{V}_{\mathrm{dc}}$ \\
0 & 1 & 0 & 0 & $-\mathrm{V}_{\mathrm{dc}}$ \\
1 & 1 & 0 & 1 & $-\mathrm{V}_{\mathrm{dc}}$ \\
0 & 0 & 0 & 1 & $-\mathrm{V}_{\mathrm{dc}}$ \\
0 & 1 & 0 & 1 & $-2 \mathrm{~V}_{\mathrm{dc}}$ \\
\hline & & & &
\end{tabular}

\section{MODULATION SCHEME}

For controlling the output voltage of a multilevel inverter, many control techniques are employed. One of the methods is Sinusoidal Pulse Width Modulation (SPWM) that is proposed in this paper. The SPWM method is applied in the proposed inverter since, it has advantages over other methods. This technique reduces distortion and eliminates the low order harmonics in the output voltage. By comparing a sinusoidal reference signal with a triangular carrier wave of frequency, the gating signals are generated. The width of each pulse is varied proportional to the amplitude of the sine wave. In this method, for a given DC input voltage, a controlled AC output voltage can be obtained by controlling the ON and OFF period of the inverter switches. This paper focuses on phase disposition PWM (PDPWM) method. In this method, all the carriers have same amplitude, frequency and phase.

\section{Z-SOURCE BASED MULITILEVEL INVERTER}

Figure 3 shows the cascaded five level Z-source based multilevel inverter (ZSMLI). It has separate DC sources for each module with same voltage level. Presence of impedance network between DC source and main circuit overcomes the limitations of the traditional inverters. In the traditional voltage source inverter, the AC output voltage is below the DC input voltage and the dead time has to be introduced for both upper and lower devices which leads to distortion of output waveform. But the Z-source multilevel inverter can buck and boost the given input voltage. 


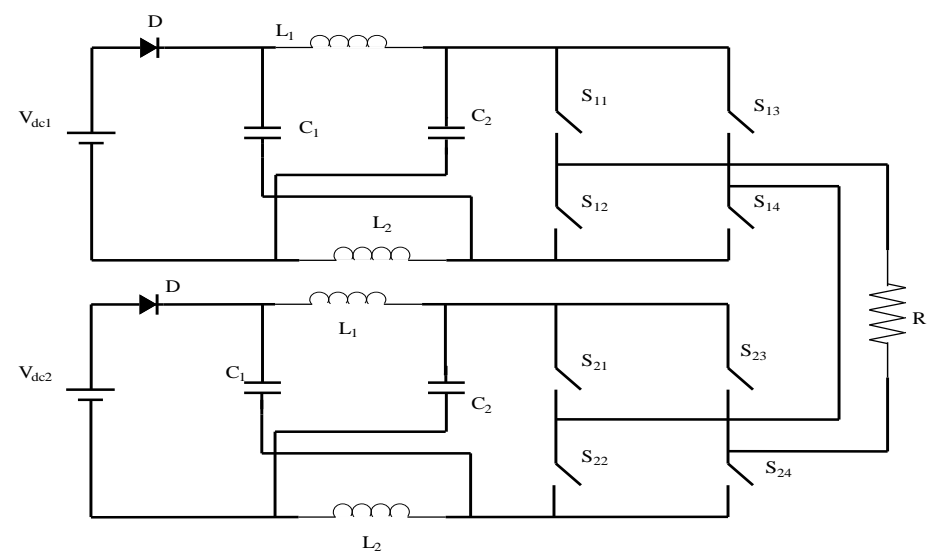

Figure 3. Z-source based multilevel inverter

\subsection{Shoot through State}

Shoot through state of Z-source inverter is shown in Figure 4. When the Z-source inverter operates in shoot through state ${ }_{2}$ the diode is turn off and disconnect the supply from impedance network.

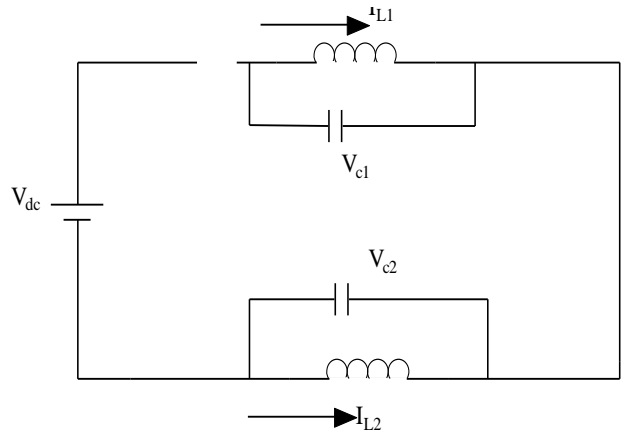

Figure 4. Shoot through state

$$
\begin{aligned}
& V_{C}=V_{L} \\
& V_{i}=0
\end{aligned}
$$

\subsection{Non Shoot through State}

Figure 5 displays the non-shoot through state of the Z-source inverter. During this state, the diode connected in series with the DC source is forward biased and the impedance network connected with the DC source. The capacitors in the impedance network are being charged and the inductors act as an additional current source. So the inverter side voltage is boosted.

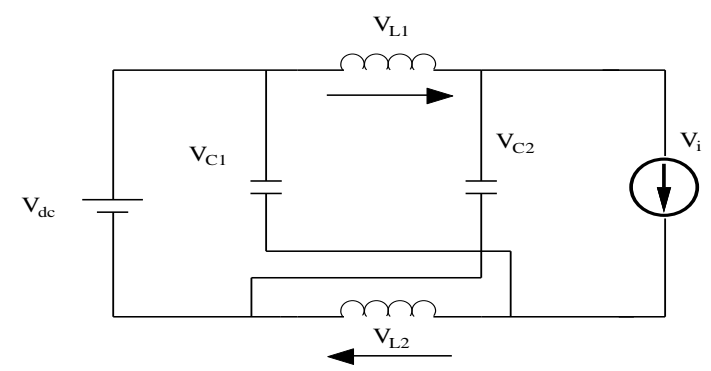

Figure 5. Non-shoot through state 


$$
V_{d c}=V_{L}+V_{C} \quad ; \quad V_{i}=V_{c}-V_{L}=2 V_{C}-V_{d c}
$$

\section{QUASI Z-SOURCE BASED MULTILEVEL INVERTER}

Quasi Z-source inverter (qZSI) is modified form of Z-source inverter in which there is difference in the impedance network.

Block diagram representation of the qZSI is shown in Figure 6. It composed of DC source, quasi network and inverter. Supply from DC source is given to the quasi network. After boosting, it is given to the inverter and the output is connected to the load.

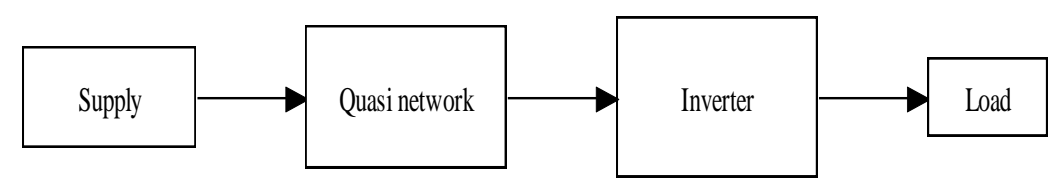

Figure 6. Block diagram of proposed Quasi Z-source inverter

The topology of the five level quasi Z-source multilevel inverter (qZSMLI) is shown in figure 7. The qZS network consist of two inductors L1 and L2, two capacitors C1 and C2, and one diode D1. It has shoot through and non-shoot through states in continuous conduction mode. The quasi Z-source inverter topology has no disadvantages when compared to the traditional Z-source inverter. Both Z-source inverter and quasi Z-source inverter overcome the problems of the conventional voltage source inverter VSI and current source inverter CSI.

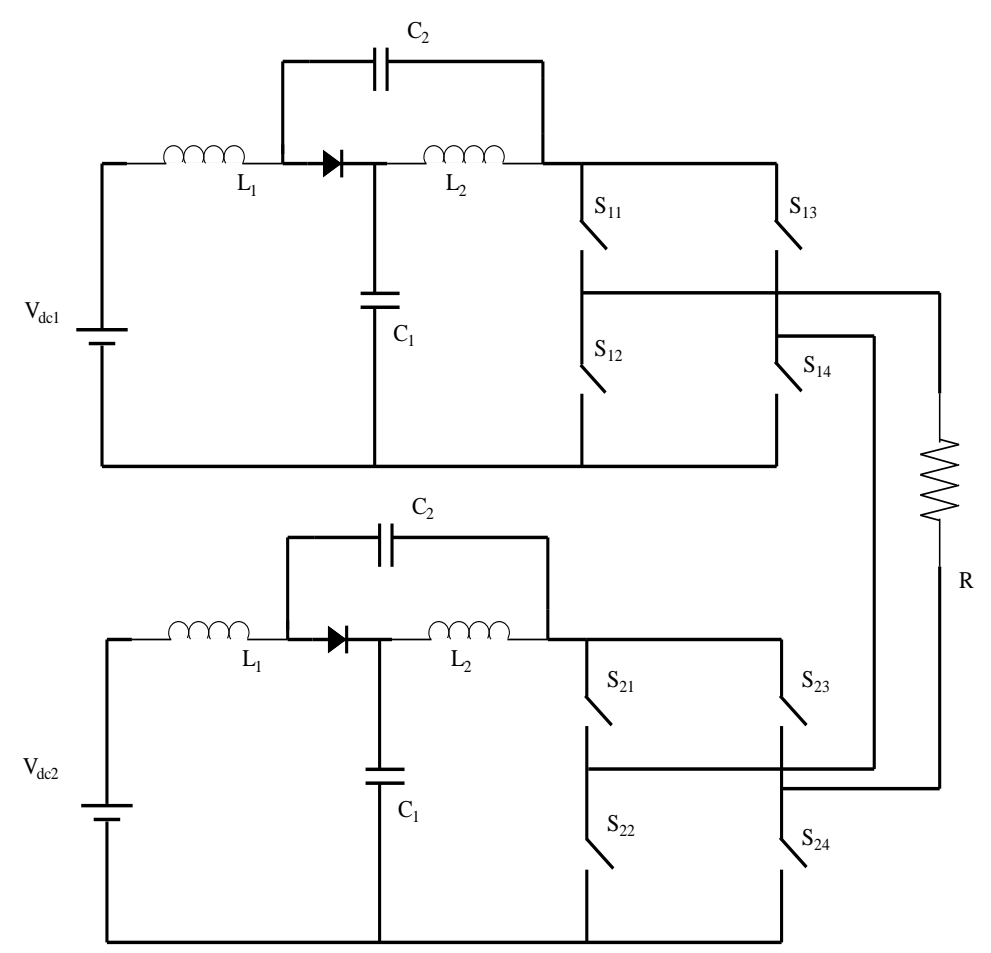

Figure 7. Quasi Z-source based multilevel inverter

\subsection{Shoot through State}

Figure 8 shows the shoot through state of the qZSI. The shoot through state is the main feature of the quasi Z-source inverter. The network utilizes shoot through states to boost the input voltage. During this state the diode is reverse biased and the obtainable inductor voltage and capacitor current represented here. 


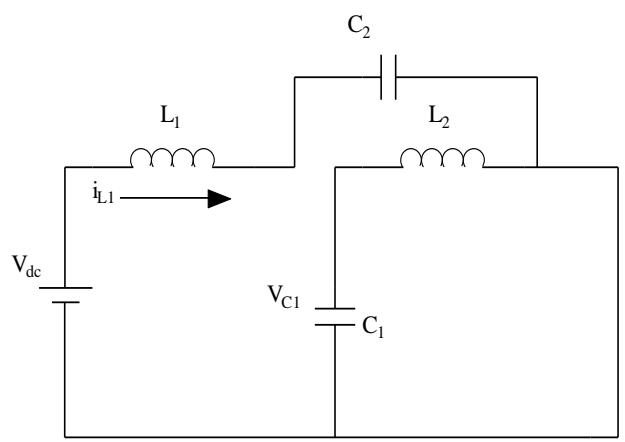

Figure 8. Shoot through state

$$
L_{1} \frac{d i_{L 1}}{d t}=V_{C 1}+R_{\text {ind }} i_{L 1} ; \quad C_{1} \frac{d V_{C 1}}{d t}=-i_{L 1}
$$

\subsection{Non-Shoot through State}

Figure 9 presents the equivalent circuit of non-shoot through state in the quasi Z-source inverter. During this state, the diode is forward biased. The following equations represent the inductor voltage and capacitor current at this case.

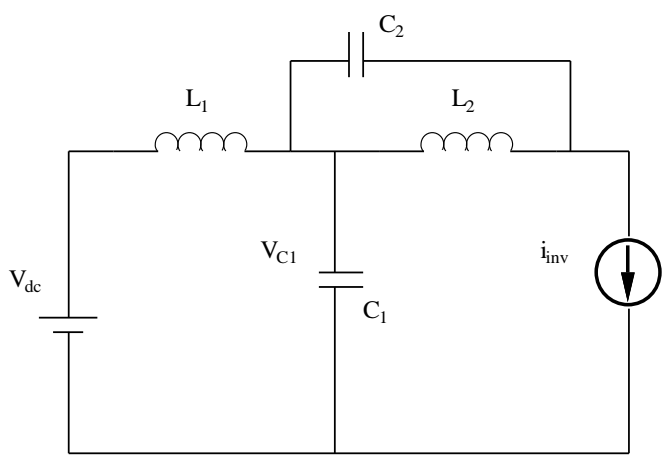

Figure 9. Non-shoot through state

$$
\begin{aligned}
& L_{1} \frac{d i_{L 1}}{d t}=V_{C 1}-V_{d c}-R_{i n d} i_{L 1} \\
& C_{1} \frac{d V_{C 1}}{d t}=i_{L 1}-i_{i n v}
\end{aligned}
$$

\section{SWITCHED INDUCTOR QUASI Z-SOURCE BASED MULTILEVEL INVERTER}

Equivalent circuit of the switched inductor quasi Z-source multilevel inverter (SL-qZSMLI) is shown in Figure 10. It comprised of three inductors, two capacitors and four diodes. The switched inductor cell composed of inductors $\mathrm{L}_{2}, \mathrm{~L}_{3}$ and diodes $\mathrm{D}_{1}, \mathrm{D}_{2}, \mathrm{D}_{3}$. 


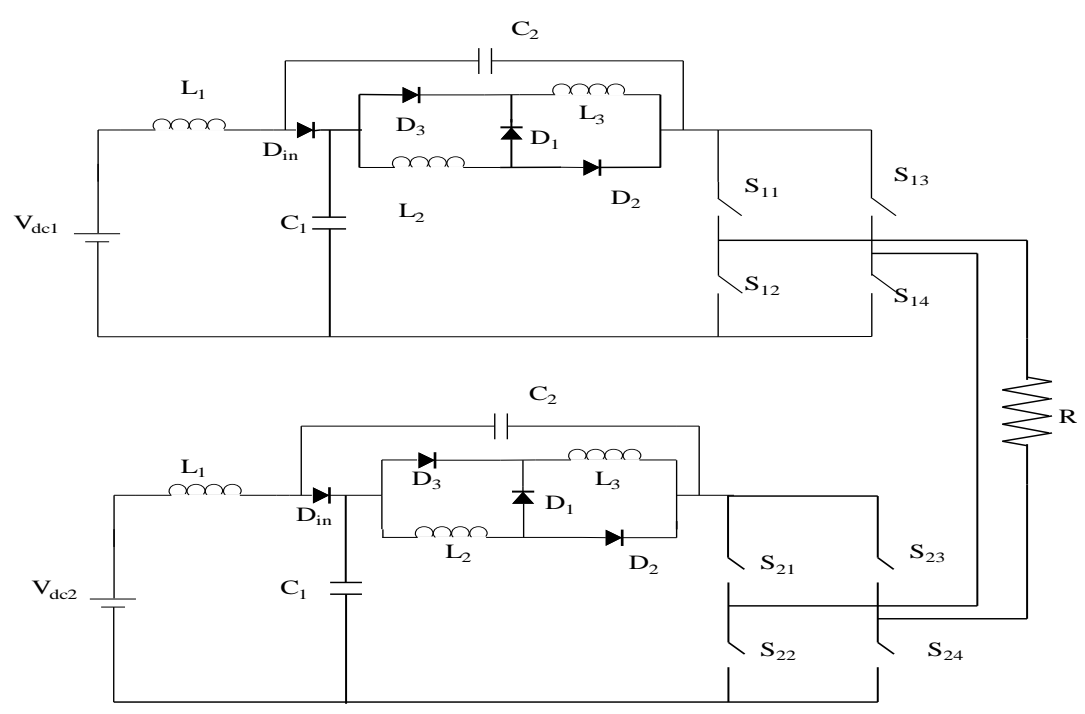

Figure 10. Proposed switched inductor quasi Z-source multilevel inverter

The proposed inverter with switched inductor topology adds only three diodes and one inductor when compared with the qZSI. This circuit provides inrush current suppression because no current flows to the main circuit at startup. The operating states of the proposed inverter topology are the shoot through and non-shoot through state.

Figure 11 and 12 displays the shoot $\mathrm{h}$ and non-shoot through states of the SL-qZSI. During nonshoot through state, diode $\mathrm{D}_{2}$ and $\mathrm{D}_{3}$ are off, while $\mathrm{D}_{\text {in }}$ and $\mathrm{D}_{1}$ are on. The inductors in switched inductor cell $\mathrm{L}_{2}$ and $\mathrm{L}_{3}$ are connected in series. The capacitors $\mathrm{C}_{1}$ and $\mathrm{C}_{2}$ are charged, while inductors $\mathrm{L}_{1}, \mathrm{~L}_{2}$, and $\mathrm{L}_{3}$ transfer energy to the main circuit from the DC source. The peak DC link voltage expressed as follows:

$$
V_{P N}=V_{C 1}+V_{C 2}
$$

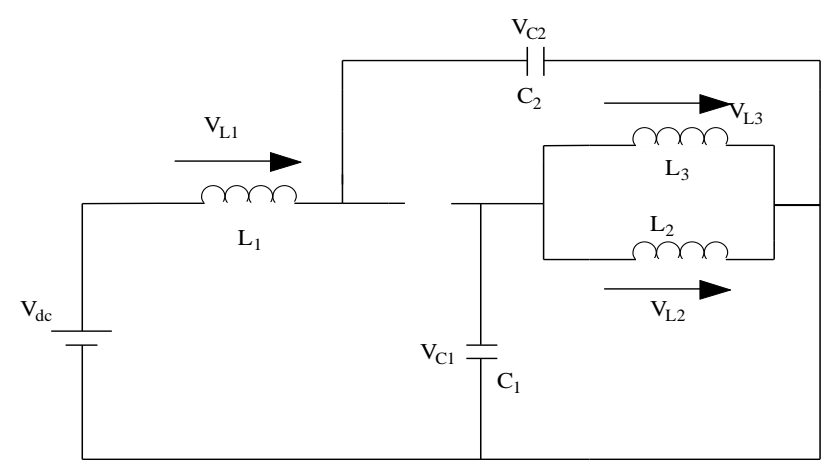

Figure 11. Shoot through state of SL-qZSI 


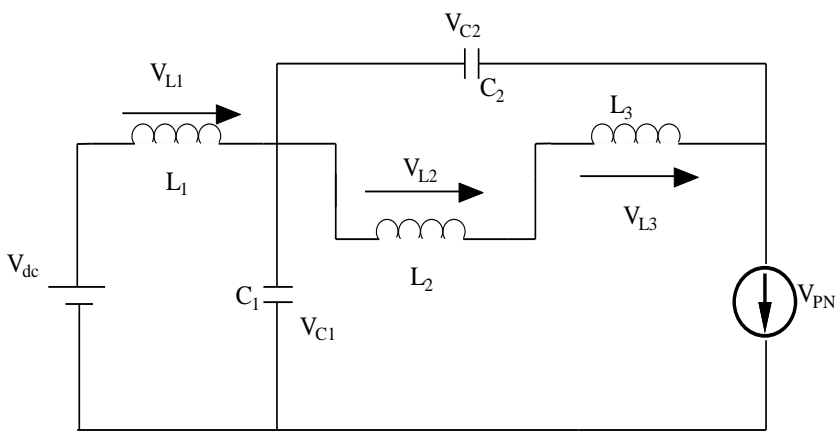

Figure 12. Non-shoot through state of the SL-qZSI

During shoot through state, diode $\mathrm{D}_{2}$ and $\mathrm{D}_{3}$ are on, while $\mathrm{D}_{\text {in }}$ and $\mathrm{D}_{1}$ are off. The inductors $\mathrm{L}_{2}$ and $\mathrm{L}_{3}$ are connected in parallel. The capacitors $\mathrm{C}_{1}$ and $\mathrm{C}_{2}$ are discharged, while inductors $\mathrm{L}_{1}, \mathrm{~L}_{2}$, and $\mathrm{L}_{3}$ are storesing energy.

$$
\begin{aligned}
& V_{L 1}=-V_{C 2}-V_{d c} \\
& V_{L 2}=V_{L 3}=-V_{C 1}
\end{aligned}
$$

\section{IMPROVED SWITCHED INDUCTOR QUASI Z-SOURCE BASED MULTILEVEL INVERTER}

The proposed topology to improve the SL-qZSI for better performance is presented in the Figure 13. The proposed topology enhances much higher boost ability. In the improved SL-qZSI topology compared with the traditional SL-qZSI, a diode $\mathrm{D}_{1}$ in the switched inductor cell is replaced by a capacitor $\mathrm{C}_{3}$. The operating principle of the proposed improved topology is similar to the traditional SL-qZSI. Figure 14 and 15 represents the shoot through and non-shoot through states of the proposed improved SL-qZSI.

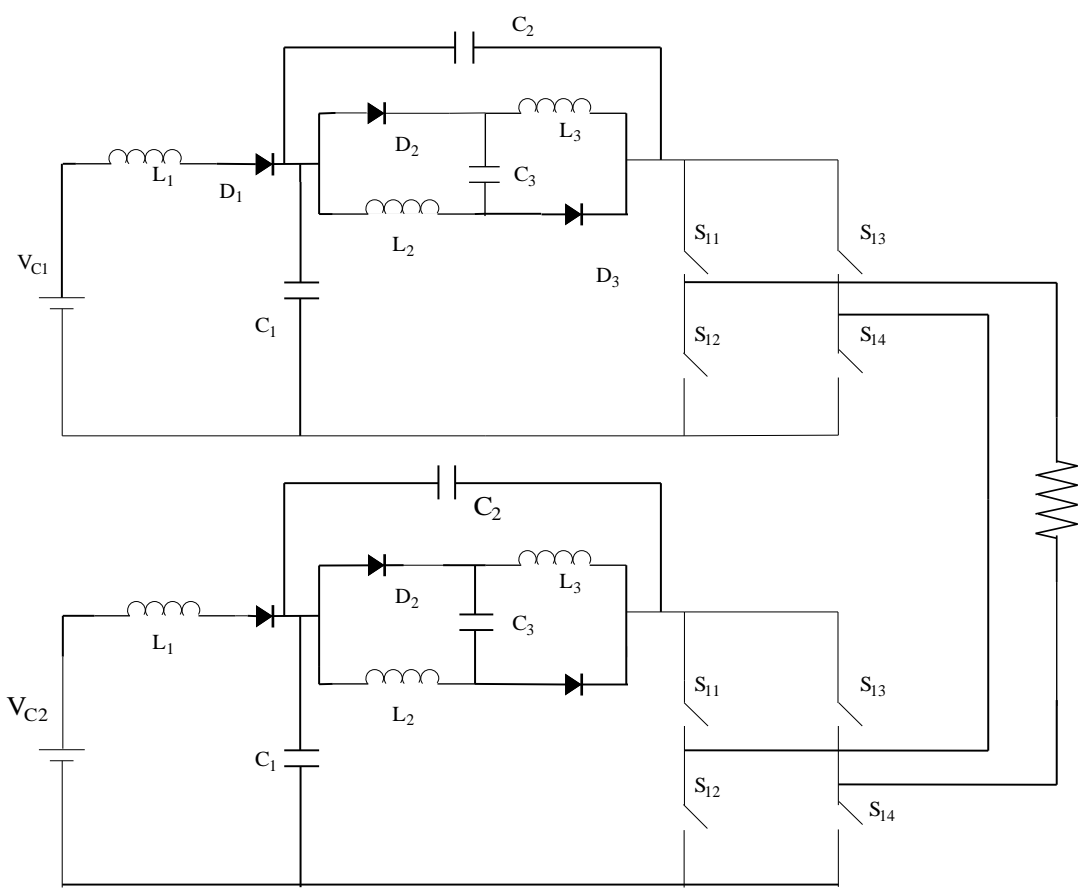

Figure 13. Proposed improved switched inductor quasi Z-source multilevel inverter 
During the shoot through state, the diodes $\mathrm{D}_{2}$ and $\mathrm{D}_{3}$ are on, while $\mathrm{D}_{1}$ is off. Inductors $\mathrm{L}_{2}, \mathrm{~L}_{3}$ and capacitor $C_{3}$ in the switched inductor cell are connected in parallel. $C_{1}$ and $C_{2}$ are discharged, while $C_{3}$ is charged. $\mathrm{VL}_{1}, \mathrm{VL}_{2}$ and $\mathrm{VL}_{3}$ are the corresponding voltages of inductors $\mathrm{L}_{1}, \mathrm{~L}_{2}$ and $\mathrm{L}_{3}$. Similarly, the voltage across $\mathrm{C}_{1}, \mathrm{C}_{2}$ and $\mathrm{C}_{3}$ are $\mathrm{VC}_{1}, \mathrm{VC}_{2}$ and $\mathrm{VC}_{3}$, respectively.

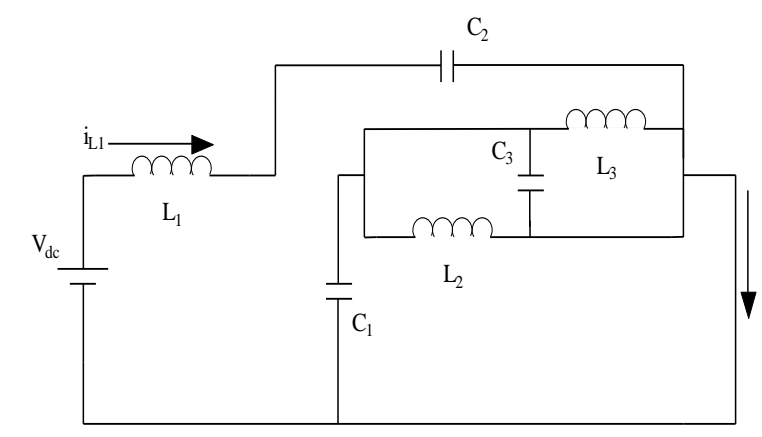

Figure 14. Shoot through state of improved SL-qZSI

Then we can get

$$
\begin{aligned}
& V_{L 1}=V_{i n}+V_{C 2} \\
& V_{C 1}=V_{C 3}=V_{L 2}=V_{L 3}
\end{aligned}
$$

During non-shoot through state, the diodes $\mathrm{D}_{2}$ and $\mathrm{D}_{3}$ are off while $\mathrm{D}_{1}$ is on. The capacitors $\mathrm{C}_{1}$ and $\mathrm{C}_{2}$ are charged, while $\mathrm{C}_{3}$ is discharged. Inductors $\mathrm{L}_{2}, \mathrm{~L}_{3}$ and capacitor $\mathrm{C}_{3}$ are connected in series. All the inductors $\mathrm{L}_{1}, \mathrm{~L}_{2}$ and $\mathrm{L}_{3}$ transfer energy to the load from DC source.

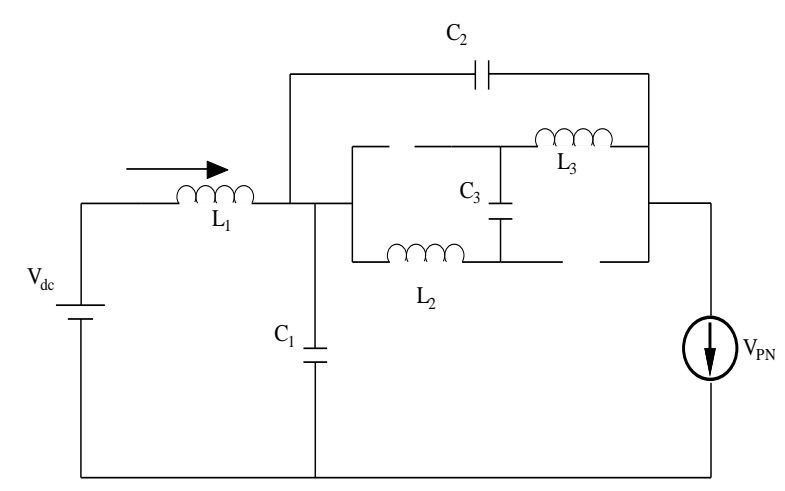

Figure 15. Non-shoot through state of improved SL-qZSI

$$
\begin{aligned}
& V_{C 1}=V_{i n}+V_{L 1} \\
& V_{C 2}=V_{C 3}+V_{L 2}+V_{L 3} \\
& V_{P N}=V_{C 1}+V_{C 2}
\end{aligned}
$$




\section{SIMULATION RESULTS}

To analyse the performance of the proposed topologies, the simulation is conducted by MATLAB/simulink. The performance parameters RMS output voltage, THD and DC component in the output waveform are observed for various impedance network values ( $\mathrm{L}$ and $\mathrm{C}$ ). They are observed by using FFT analysis. In this work, five level output is generated by using PDPWM technique. Table 2 represents the simulation parameters. For example, the output waveform and harmonic spectrum of the ZSMLI, qZSMLI, SL-qZSMLI and improved SL-qZSI for $\mathrm{L}=250 \mu \mathrm{H}$ and $\mathrm{C}=500 \mu \mathrm{F}$ are shown in the following figures.

\begin{tabular}{ccc}
\multicolumn{2}{c}{ Table 2. Simulation Parameters } \\
\hline \multicolumn{2}{c}{ Input DC voltage } & $100 \mathrm{~V}$ \\
\hline & $\mathrm{L}$ & $3 \mathrm{mH}$ \\
& $250 \mu \mathrm{H}$ \\
Impedance & & $160 \mu \mathrm{H}$ \\
network & & $4700 \mu \mathrm{F}$ \\
& $\mathrm{C}$ & $470 \mu \mathrm{F}$ \\
& & $500 \mu \mathrm{F}$ \\
& Lf & $3000 \mu \mathrm{mH}$ \\
Output filter & $\mathrm{Cf}$ & $4700 \mu \mathrm{F}$ \\
Resistive load & $\mathrm{R}$ & $10 \mathrm{ohms}$ \\
\hline
\end{tabular}

\subsection{Z-source Inverter with Filter}

Figure 16 represents the output voltage and harmonic spectrum of the ZSMLI with filter condition. A fundamental output voltage of $419.5 \mathrm{~V}$ and THD of $8.89 \%$ obtained are shown in Figure 16.

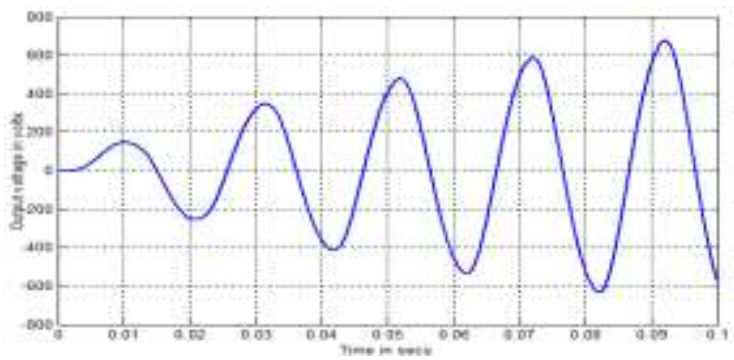

a. Output voltage

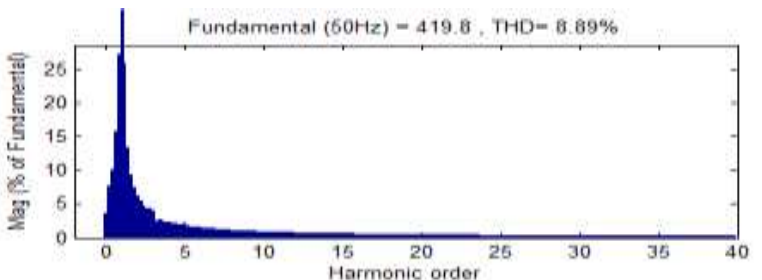

b. Harmonic spectrum

Figure 16. Z-source multilevel inverter

\subsection{Quasi Z-Source Inverter with Filter}

Figure 17 shows the output voltage waveform and harmonic spectrum of the qZSMLI with filter that they are observed using FFT analysis. The fundamental output voltage of $411.1 \mathrm{~V}$ and THD of $8.90 \%$ are obtained shown in the figure.

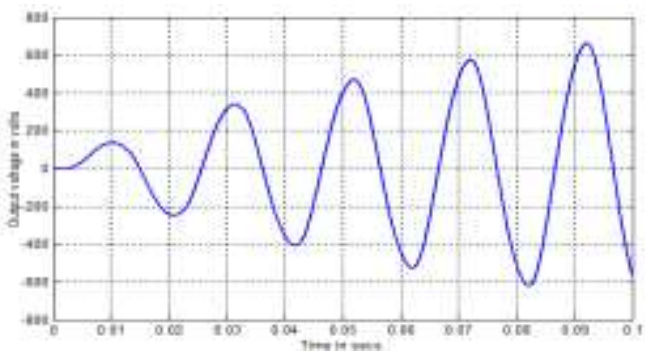

a. Output voltage

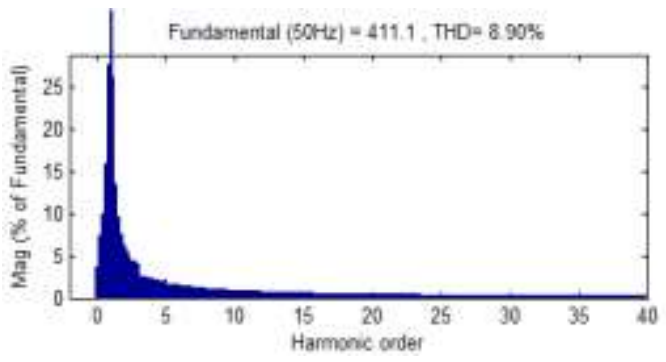

b. harmonic spectrum

Figure 17. Quasi Z-source multilevel inverter 


\subsection{Switched Inductor Quasi Z-source Inverter with Filter}

Figure 18 shows the output voltage and harmonic spectrum of the SL-qZSI. the fundamental output voltage of $455.9 \mathrm{~V}$ and THD of $7.43 \%$ are obtained shown in the figure.

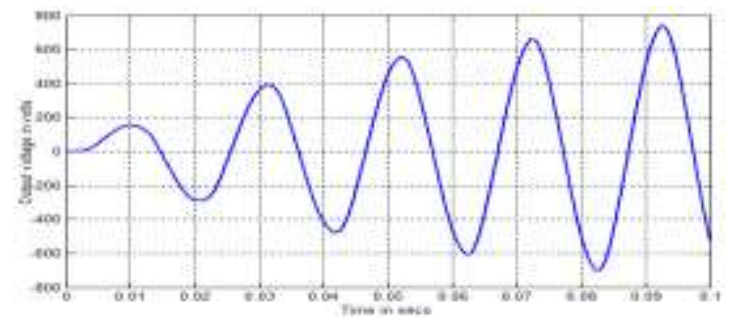

a. Output voltage

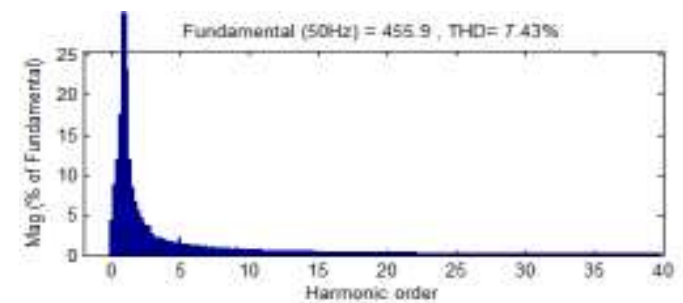

b. Harmonic spectrum

Figure 18. Switched inductor Quasi Z-source multilevel inverter

\subsection{Improved Switched Inductor Quasi Z-Source Inverter with Filter}

Figure 19 displays the output voltage and harmonic spectrum of the improved SL-qZSI. The fundamental output voltage of $515.1 \mathrm{~V}$ and THD of $6.47 \%$ are obtained are shown in the figure.

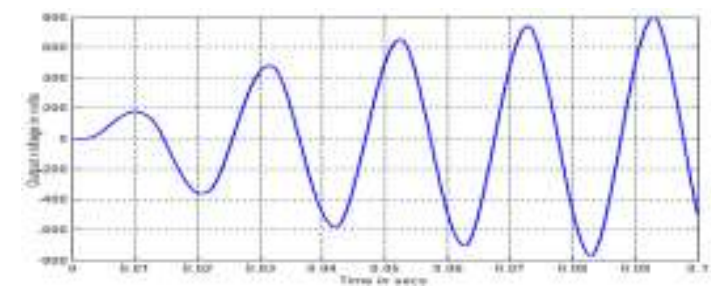

a. Output voltage

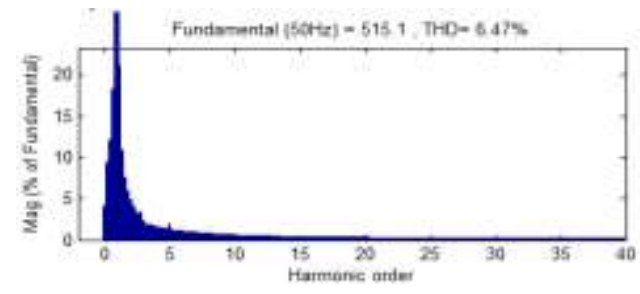

b. Harmonic spectrum

Figure 19. Improved switched inductor quasi Z-source multilevel inverter

In this analysis, presence of the RMS output voltage and THD in the output voltage waveform is observed for various topologies by varying the modulation index ma. The following tables represent measurements across multilevel inverter. Table 3 shows the measurement across the MLI for $\mathrm{L}=3 \mathrm{mH}$, $\mathrm{C}=4700 \mu \mathrm{F}$, while Table 4 is with $\mathrm{L}=3 \mathrm{mH}, \mathrm{C}=470 \mu \mathrm{F}$. Table 5 represents the measurement across the MLI for $\mathrm{L}=250 \mu \mathrm{H}, \mathrm{C}=500 \mu \mathrm{F}$, while Table 6 is with $\mathrm{L}=160 \mu \mathrm{H}, \mathrm{C}=1000 \mu \mathrm{F}$.

Table 3. Measurement Across the MLI for $\mathrm{L}=3 \mathrm{mH}$ and $\mathrm{C}=4700 \mu \mathrm{F}$

\begin{tabular}{ccccccccc}
\hline \multirow{2}{*}{ ma } & \multicolumn{2}{c}{ ZSMLI } & \multicolumn{2}{c}{ q-ZSMLI } & \multicolumn{2}{c}{ SL-qZSMLI } & \multicolumn{2}{c}{ Improved SL-qZSMLI } \\
\cline { 2 - 8 } & RMS (V) & THD (\%) & RMS (V) & THD (\%) & RMS (V) & THD (\%) & RMS (V) & THD (\%) \\
\hline 1 & 86.8 & $6.63 \%$ & 88.4 & $7.10 \%$ & 130.3 & $6.42 \%$ & 221.5 & $5.34 \%$ \\
0.9 & 167.7 & $7.16 \%$ & 166.4 & $7.36 \%$ & 204.4 & $7.73 \%$ & 213.5 & $5 \%$ \\
0.8 & 105 & $5.86 \%$ & 103 & $6.17 \%$ & 176.5 & $7.75 \%$ & 193.6 & $4.92 \%$ \\
0.7 & 22.79 & $9.55 \%$ & 21.98 & $9.07 \%$ & 80.88 & $6.99 \%$ & 134.4 & $5.15 \%$ \\
0.6 & 24.65 & $10.57 \%$ & 24.28 & $11.14 \%$ & 99.31 & $6.32 \%$ & 110.9 & $6.63 \%$ \\
\hline
\end{tabular}

Table 4. Measurement Across the MLI for $\mathrm{L}=3 \mathrm{mH}$ and $\mathrm{C}=470 \mu \mathrm{F}$

\begin{tabular}{|c|c|c|c|c|c|c|c|c|}
\hline \multirow{2}{*}{$\mathrm{ma}$} & \multicolumn{2}{|c|}{ ZSMLI } & \multicolumn{3}{|c|}{ q-ZSMLI } & \multirow{2}{*}{$\begin{array}{c}\text { SL-qZSMLI } \\
\text { THD }(\%)\end{array}$} & \multicolumn{2}{|c|}{ Improved SL-qZSMLI } \\
\hline & RMS (V) & THD (\%) & RMS (V) & THD (\%) & RMS (V) & & RMS (V) & THD (\%) \\
\hline 1 & 93.75 & $7.25 \%$ & 92.76 & $7.28 \%$ & 101.1 & $8.85 \%$ & 215.6 & $12.11 \%$ \\
\hline 0.9 & 195.2 & $8.20 \%$ & 192.9 & $8.24 \%$ & 212.6 & $10.18 \%$ & 210.5 & $12.05 \%$ \\
\hline 0.8 & 78.52 & $12.63 \%$ & 78.62 & $12.50 \%$ & 183.2 & $9.06 \%$ & 223.7 & $9.54 \%$ \\
\hline 0.7 & 16.18 & $15.74 \%$ & 16.46 & $15.12 \%$ & 90.91 & $12.24 \%$ & 160.2 & $6.98 \%$ \\
\hline 0.6 & 20.46 & $14.98 \%$ & 20.39 & $14.97 \%$ & 103.2 & $11.84 \%$ & 167.5 & $6.37 \%$ \\
\hline
\end{tabular}


Table 5. Measurement Across the MLI for $\mathrm{L}=250 \mu \mathrm{H}$ and $\mathrm{C}=500 \mu \mathrm{F}$

\begin{tabular}{ccccccccc}
\hline \multirow{2}{*}{ ma } & \multicolumn{2}{c}{ ZSMLI } & \multicolumn{2}{c}{ q-ZSMLI } & \multicolumn{2}{c}{ SL-qZSMLI } & \multicolumn{2}{c}{ Improved SL-qZSMLI } \\
\cline { 2 - 8 } & RMS(V) & THD (\%) & RMS (V) & THD (\%) & RMS (V) & THD (\%) & RMS (V) & THD (\%) \\
\hline 1 & 296.8 & $8.89 \%$ & 290.7 & $8.90 \%$ & 322.4 & $7.43 \%$ & 364.2 & $6.47 \%$ \\
0.9 & 328.1 & $9.09 \%$ & 321.1 & $9.13 \%$ & 333.4 & $7.99 \%$ & 348.6 & $6.60 \%$ \\
0.8 & 278.8 & $13.40 \%$ & 272 & $13.39 \%$ & 330.2 & $7.60 \%$ & 374.7 & $6.62 \%$ \\
0.7 & 80.78 & $8.34 \%$ & 79.28 & $8.27 \%$ & 254.4 & $8.65 \%$ & 385.2 & $8.09 \%$ \\
0.6 & 79.93 & $8.78 \%$ & 78.34 & $8.72 \%$ & 222.2 & $9.14 \%$ & 436.7 & $7.22 \%$ \\
\hline
\end{tabular}

Table 6. Measurement Across the MLI for $\mathrm{L}=160 \mu \mathrm{H}$ and $\mathrm{C}=1000 \mu \mathrm{F}$

\begin{tabular}{ccccccccc}
\hline \multirow{2}{*}{ ma } & \multicolumn{2}{c}{ ZSMLI } & \multicolumn{2}{c}{ q-ZSMLI } & \multicolumn{2}{c}{ SL-qZSMLI } & \multicolumn{2}{c}{ Improved SL-qZSMLI } \\
\cline { 2 - 8 } & RMS(V) & THD (\%) & RMS (V) & THD (\%) & RMS (V) & THD (\%) & RMS (V) & THD (\%) \\
\hline 1 & 325.1 & $6.88 \%$ & 319.2 & $6.88 \%$ & 358.9 & $7.45 \%$ & 405.3 & $6.47 \%$ \\
0.9 & 352.8 & $7.59 \%$ & 344.1 & $7.61 \%$ & 369.3 & $7.05 \%$ & 383 & $5.77 \%$ \\
0.8 & 315.6 & $12.10 \%$ & 305.7 & $12.03 \%$ & 387.3 & $7.28 \%$ & 436.1 & $6.34 \%$ \\
0.7 & 95.36 & $11.04 \%$ & 93.38 & $10.81 \%$ & 283.3 & $8.06 \%$ & 427.9 & $6.64 \%$ \\
0.6 & 104.4 & $10.89 \%$ & 101.4 & $10.84 \%$ & 237.5 & $9.42 \%$ & 470.6 & $5.96 \%$ \\
\hline
\end{tabular}

\section{CONCLUSION}

The performance of the Z-source multilevel inverter, quasi Z-source multilevel inverter, switched inductor quasi Z-source multilevel inverter and improved switched inductor quasi Z-source multilevel inverter are analysed in this work. Simulation was carried out for the proposed topologies using the PWM technique. The RMS output voltage and THD are observed using FFT analysis in MATLAB. The Improved switched inductor quasi Z-source based MLI has higher boost ability compared with other topologies. From the analysis of each proposed topology by varying impedance network values ( $\mathrm{L}$ and $\mathrm{C}$ ), the developed improved switched inductor quasi Z-source multilevel inverter provides high boost ability. In this inverter, higher RMS voltage $(470.6 \mathrm{~V})$ is obtained by choosing $\mathrm{L}=160 \mu \mathrm{H}$ and $\mathrm{C}=1000 \mu \mathrm{F}$. It can be seen that the THD is the lesser (4.92\%) for the five level improved SL-qZSMLI configuration by selecting L=3mH and $\mathrm{C}=4700 \mu \mathrm{F}$. Some of the important industrial applications of inverters are Variable speed AC motor drives, Uninterruptible Power Supplies, Induction heating, High voltage DC transmission lines, Aircraft power supplies and Battery vehicle drives. UPSs are emergency power sources which have widespread application in critical equipments such as computers, automated process controllers and hospital instruments. It is a big challenge for a UPS to maintain high quality sinusoidal output voltage under all loading conditions. In this work for impedance source PWM inverters may be employed in UPS and other applications. In high power and high voltage applications, the three level inverters have some limitations in operating at high frequency mainly due to switching losses and constraints of device rating. Impedance source based multilevel inverters have been extensively used in high power applications because then can realize high voltage and high power output through the use of semiconductor switches without use of transformer and without dynamic voltage balance circuits.

\section{REFERENCES}

[1] Nguyen M.K, Lim Y.C, Choi J.H, Two Switched Inductor Quasi Z-Source Inverters, IET Power Electronics. 2012; 5(7): 1017-1025.

[2] Divya Subramanian, Rebiya Rasheed, Five Level cascaded H-Bridge Multilevel Inverter Using Multicarrier Pulse Width Modulation Technique, International Journal of Engineering and Innovative Technology, 2013; 3(1): 438441.

[3] Dinakaran C, Panthee A.B, Eswaramma K, Modelling and Control of Quasi Z-Source Inverter for Advanced Power Conditioning of Renewable Energy Systems. International Journal of Advanced Research in Electrical, Electronics, and Instrumentation Engineering. 2014; 3(2): 136-141.

[4] Farshad Khosravi-, Naziha Ahmad Azli-, Avin Kaykhosravi1., Design of a Reduced Component Count SinglePhase-to Three-Phase quasi Z-Source Converter, IET Power Electronics, 2014; 7(3): 489-495.

[5] Kohila, J., Munia Raj, R., Kannan, S., Z-Source Multilevel Inverter for Photovoltaic Application, International Journal of Innovative Research in Science, Engineering and Technology, 2014; 3(3): 492-297.

[6] Chougule, G., Gaikwad, A., Simulation Study of Quasi Z-Source Inverter for Resistive and Inductive Load, International Journal of Innovations in Engineering Research and Technology, 2015; 2(6): 2-13.

[7] Rohitash Singh, Saurabh Kr. Bajpai, Harinder Singh Sandhu, Comparative Study of PWM Control and PI Control of Induction Motor, Bulletin of Electrical Engineering and Informatics (BEEI), 2015; 4(1): 53-58.

[8] Sengolrajan T, Shanthi B, Arumugam M, Three Phase Trinary Source MLI Using Multicarrier SPWM Strategies, Indonesian Journal of Electrical Engineering and Computer Science (IJEECS), 2015; 13(3): 483-492. 
[9] Elakya, V.C., Aarthi-, Teresa., V.V. High Performance Extended Switched Inductor Quasi Z-Source Inverter for Three Phase Loads, International Journal of Innovative Research in Science, Engineering and Technology, 2015; 4(4): 76-81

[10] Liqiang Yang, Dongyuan Qiu, Bo Zhang, High-Performance Quasi Z-Source Inverter with Low Capacitor Voltage Stress and Small Inductance, IET Power Electronics, 2015; 8(6): 1061-1067

[11] Devaraj N, Reena A, Reduction of switches and DC sources in Cascaded Multilevel inverter, Bulletin of Electrical Engineering and Informatics (BEEI), 2015; 4(3): 186-195.

[12] Sobhan Dorahaki, A Survey on Maximum Power Point Tracking Methods in Photovoltaic Power Systems, Bulletin of Electrical Engineering and Informatics (BEEI), 2015; 4(3): 169-175.

[13] Einstien Jackson S., Implementation of Switched Inductor Quasi Z-Source Inverter, International Journal of Pharmacy and Technology, 2016; 8(4): 23769-23779

[14] Bhujangaro, Y., Bhavani, T., Implementation of Cascaded H-bridge Multilevel Inverter for Sinusoidal PWM Controller Fed Induction Motor Drive, International Journal of Advanced Technology and Innovative Research, 2016; 8(9): 1870-1876

[15] Gaddafi Sani Shehu., Abdullahi Bala Kunya., Ibrahim Haruna Shanono., A Review of Multilevel Inverter Topology and Control Techniques, Journal of Automation and Control Engineering, 2016; 4(3): 233-241

[16] Himanshu-, Rintu Khanna-, Neelu Jain-, A Survey on Various Topologies of Z-Source Inverters, International Journal of Electrical and Electronics Engineering, 2016; 3(7): 5-9.

[17] Nishamol, P.T., Jassia, M.A., Single Phase Switched- Capacitor/ Switched-Inductor Quasi -Z-Source Inverter, International Journal of Innovative Research in Science, Engineering and Technology, 2016; 5(8): 14935-14943.

[18] H.Yuyao., L. Hailong., F. Wei., Novel Cascaded Z-Source Neutral Point Clamped Inverter, Chinese Journal of Electronics, 2016; 25(5): 965-973

[19] Mahmooda Mubeen=, Design of Z-Source Inverter for Voltage Boost Applications', International Journal of Innovative Research in Electrical, Electronics, Instrumentation and Control Engineering, 2016; 4(2): 136-140

[20] Asadei D, Serra G, Tani K., Implementation of a Direct Control Algorithm for Induction Motors Based on Discrete Space Vector Modulation, IEEE Transactions on Power Electronics. 2007; 15(4): 769-777.

[21] Vijayalakshmi K, Balamurugan C.R, A Review on Z-Source Based Multilevel Inverter with Reduced Number of Switches, 2016 International Conference on Engineering and Technology (ICET), Karpagam College of Engineering, Coimbatore, ISBN: 978-1-5090-3212-9, 16th and 17th, Dec 2016.

[22] Vijayalakshmi K, Balamurugan C.R, Simulation and Analysis of Improved Switched Inductor Quasi Z-Source Based Multilevel Inverter with Reduced Number of Switches, International Conference On Emerging Trends In Science, Engineering \& Technology, Jerusalem College Of Engineering, Chennai, 18th and 19th, March 2017.

[23] Revathi, S.M, Balamurugan, C.R, A Review on Various Z-Source Fed Multilevel Inverter, 10th International Conference on Recent Innovations in Science, Engineering and Management, 978-93-86171-53-5, Dhruva Institute of Engineering and Technology, Nalgonda, July 7th, 2017, pp. 38-47.

[24] Vijayalakshmi, K, Balamurugan, C.R, Investigations on Z-source based cascaded five level inverter, International Journal of Signal Processing, Image Processing and Pattern Recognition, 2016; 9(12): 37 - 50.

[25] Balamurugan, C.R, Natarajan, S.P, Bensraj, R, Shanthi, B, A Review on modulation Strategies of Multilevel Inverter, Indonesian Journal of Electrical Engineering and Computer Science (IJEECS), 2016; 3(3): 681 - 705.

[26] Balamurugan C.R, Natarajan, S.P, Anandhi, T.S, Performance Evaluation of $3 \Phi$ Asymmetrical MLI with Reduced Switch Count, Indonesian Journal of Electrical Engineering and Computer Science (IJEECS), 2016; 3(3): 671 680.

[27] Balamurugan, C.R, Natarajan, S.P, Anandhi, T.S, Besnraj, R, Hardware Implementation of Cascaded Hybrid Multilevel Inverter with Reduced Number of Switches, Indonesian Journal of Electrical Engineering and Computer Science (IJEECS), 2016; 3(2): 314 - 322.

[28] Vijayalakshmi, K, Balamurugan, C.R, Z Source Multilevel Inverter Based on Embedded Controller, Indonesian Journal of Electrical Engineering and Computer Science (IJEECS), 2017; 6(1): 1-8. 